\title{
Restriction Fragment Length Polymorphism Analysis of PCR-Amplified 16S Ribosomal DNA for Rapid Identification of Saccharomonospora Strains
}

\author{
JUNG-HOON YOON, ${ }^{1,2}$ SUNG TAIK LEE, ${ }^{2}$ SAM-BONG KIM, ${ }^{1}$ WON YONG KIM, ${ }^{1}$ \\ MICHAEL GOODFELLOW, ${ }^{3}$ AND YONG-HA PARK ${ }^{1 *}$ \\ Bioinformatics \& Systematics Laboratory, Korean Collection for Type Cultures, Korea Research Institute of \\ Bioscience and Biotechnology, Korea Institute of Science and Technology, Daeduk Science Park, ${ }^{1}$ and \\ Department of Biological Science, Korea Advanced Institute of Science and Technology, ${ }^{2}$ Taejeon, \\ Republic of Korea, and Department of Microbiology, The Medical School, University of Newcastle \\ upon Tyne, Framlington Place, Newcastle upon Tyne, NE2 4HH, United Kingdom ${ }^{3}$
}

\begin{abstract}
Twenty-one strains of Saccharomonospora azurea, Saccharomonospora cyanea, Saccharomonospora glauca, Saccharomonospora viridis, and "Saccharomonospora caesia" were examined to evaluate the discriminatory value of $16 \mathrm{~S}$ ribosomal DNA (rDNA) fingerprints. The $16 \mathrm{~S}$ rDNAs were amplified by PCR by using oligonucleotide primers complementary to 16S rRNA genes. A restriction fragment length polymorphism (RFLP) analysis of the 16S rDNAs was performed with SmaI and $M l u I$. The four validly described Saccharomonospora species could be differentiated on the basis of their characteristic $16 \mathrm{~S}$ rDNA restriction patterns. The strains of " $S$. caesia" gave a restriction pattern identical to that of $S$. azurea $\mathrm{K}_{161}{ }^{\mathrm{T}}(\mathrm{T}=$ type strain). This result was anticipated from the previous report that $S$. azurea $\mathrm{K161}^{\mathrm{T}}$ and the strains of " $S$. caesia" have identical $16 \mathrm{~S}$ rRNA sequences. We found that purification of amplified 16S rDNA products following PCR was necessary for our RFLP analysis.
\end{abstract}

The genus Saccharomonospora was first proposed by Nonomura and Ohara (13) for monosporic actinomycetes containing meso-diaminopimelic acid, arabinose, and galactose in the peptidoglycan (wall chemotype IV sensu Lechevalier and Lechevalier (12)). This genus is a genus of gram-positive, aerobic, non-acid-fast actinomycetes with non-motile spores that typically form nonfragmenting, branched substrate mycelia (13). $16 \mathrm{~S}$ rRNA sequence data have shown that the genus is a distinct homogeneous group within the evolutionary radiation encompassed by the family Pseudonocardiaceae (9).

Up to this point, the genus Saccharomonospora has been described as a genus with four valid species, namely, Saccharomonospora azurea (14), Saccharomonospora cyanea (15), Saccharomonospora glauca (4), and Saccharomonospora viridis (13). "Saccharomonospora caesia" was proposed as a fifth species by Greiner-Mai et al. (5) for strains previously classified as Micropolyspora caesia $(7,10)$. However, this species was not included on the Approved Lists of Bacterial Names (17) and has not been validly published on subsequent Approved Lists. It has been found recently that strains of " $S$. caesia" are very closely related to $S$. azurea $\mathrm{K} 161^{\mathrm{T}}(\mathrm{T}=$ type strain) as determined by numerical phenetic studies (8) and data based on nucleic acid techniques $(9,21)$, and more investigations are needed to determine the detailed relationship between the two species. It has been determined that strains of $S$. viridis cause farmer's lung disease $(1,3)$ and are significant agents of hypersensitivity pneumonitis (11). Therefore, it is important to be able to distinguish rapidly among the existing taxa and between validly published and putatively novel Saccharomonospora species.

rRNAs, especially the $16 \mathrm{~S}$ or $18 \mathrm{~S}$ rRNA genes, have been widely studied both in prokaryotes and in eukaryotes $(19,20)$. Because the $16 \mathrm{~S}$ rRNA gene contains highly conserved regions

* Corresponding author. Phone: 82-42-860-4620. Fax: 82-42-8604625. E-mail: yhpark@gerigw.geri.re.kr. found in all prokaryotic organisms and diagnostic variable sequence regions that are unique to particular organisms, it has been used to determine phylogenetic relationships between bacterial species $(19,20)$ and has also been used in the classification and identification of Saccharomonospora species (9). However, since sequence analysis of $16 \mathrm{~S}$ rRNA is somewhat expensive and time-consuming, there are difficulties in routine application of this technique to rapid identification of large numbers of strains.

In this study, PCR-amplified $16 \mathrm{~S}$ ribosomal DNAs (rDNAs) of 21 strains of the genus Saccharomonospora were analyzed on the basis of their restriction fragment length polymorphisms (RFLPs). The usefulness of PCR-RFLP analysis for rapid identification of members of the genus Saccharomonospora was examined. The existence of differences between digests of purified and unpurified PCR products was also investigated.

\section{MATERIALS AND METHODS}

Bacterial strains. Table 1 summarizes the bacterial strains used in this study. The sources of the bacteria have been described previously $(9,21)$. All of the test strains were grown in shake flasks containing tryptone soy broth supplemented with glucose $(0.75 \%$, wt/vol $)$ at $45^{\circ} \mathrm{C}$ for $48 \mathrm{~h}$.

Isolation of DNA. The chromosomal DNAs were isolated by the method described previously (21).

PCR amplification of 16S rDNA. The oligonucleotide primers used for amplification of $16 \mathrm{~S}$ rDNA were synthesized by KOREA BIOTECH., Inc., Taejeon, Republic of Korea. Primers annealing at the $5^{\prime}$ and $3^{\prime}$ ends of the $16 S$ rRNA genes were 5'-GAGTT TGATC CTGGC TCAG-3' (positions 9 to 27 [Escherichia coli 16S rRNA numbering]) and 5'-AGAAA GGAGG TGATC CAGCC $-3^{\prime}$ (positions 1542 to 1525 [E. coli $16 \mathrm{~S}$ rRNA numbering]), respectively. PCR amplification was performed in a final reaction volume of $100 \mu \mathrm{l}$, and the reaction mixture contained each primer at a concentration of $0.5 \mu \mathrm{M}$, each deoxynucleoside triphosphate at a concentration of $200 \mu \mathrm{M}, 50 \mathrm{mM} \mathrm{KCl}, 10 \mathrm{mM}$ Tris- $\mathrm{HCl}$ ( $\mathrm{pH} \mathrm{8.3),} 1.5 \mathrm{mM} \mathrm{MgCl}_{2}, 0.01 \%$ (wt/vol) gelatin, and $2.5 \mathrm{U}$ of Taq DNA polymerase (Perkin-Elmer Co., Norwalk, Conn.). Each reaction mixture was overlaid with mineral oil, and the PCR was run for 35 cycles with a DNA thermal cycler (model 480; Perkin-Elmer Co.). The following thermal profile was used for the PCR: denaturation at $94^{\circ} \mathrm{C}$ for $1 \mathrm{~min}$, primer annealing at $60^{\circ} \mathrm{C}$ for $1 \mathrm{~min}$, and extension at $72^{\circ} \mathrm{C}$ for $2 \mathrm{~min}$. The final cycle included extension for $10 \mathrm{~min}$ at $72^{\circ} \mathrm{C}$ to ensure full extension of the products. On completion of the reaction, each reaction tube was frozen at $-70^{\circ} \mathrm{C}$ in a deep freezer for $10 \mathrm{~min}$, and then the 
TABLE 1. Strains used in this study

\begin{tabular}{|c|c|c|}
\hline Laboratory no. & Species & $\begin{array}{l}\text { Source and/or other } \\
\text { designation(s) }{ }^{a}\end{array}$ \\
\hline $\mathrm{K} 161^{\mathrm{T}}$ & S. azurea & $\begin{array}{l}\text { H. Runmao, NA-128 } \\
\left(=\text { SIIA } 86128^{\mathrm{T}}\right)\end{array}$ \\
\hline $\mathrm{K} 76^{\mathrm{T}}$ & "S. caesia" & KCTC $9152^{\mathrm{T}}$ \\
\hline K163 & "S. caesia" & DSM 43068 \\
\hline K182 & "S. caesia" & E. Greiner-Mai, Ko18 \\
\hline K200 & "S. caesia" & J. Lacey, A1932 \\
\hline SB-01, SB-22, SB-58 & "S. caesia" & S.-B. Kim \\
\hline $\mathrm{K} 168^{\mathrm{T}}$ & S. cyanea & $\begin{array}{l}\text { H. Runmao, NA-134 } \\
\left(=\text { SIIA } 86134^{\mathrm{T}}\right)\end{array}$ \\
\hline $\mathrm{K} 169^{\mathrm{T}}$ & S. glauca & DSM $43769^{T}$ \\
\hline K179 & S. glauca & A. J. McCarthy, BD-125 \\
\hline K194 & S. glauca & J. Lacey, A66 \\
\hline K195 & S. glauca & J. Lacey, A1450 \\
\hline K202 & S. glauca & J. Ruan, 350 \\
\hline SB-37 & S. glauca & S.-B. Kim \\
\hline $\mathrm{K} 73^{\mathrm{T}}$ & S. viridis & NCIB $9602^{\mathrm{T}}$ \\
\hline K185 & S. viridis & E. Greiner-Mai, L1v \\
\hline K191 & S. viridis & E. Greiner-Mai, R25 \\
\hline K197 & S. viridis & J. Lacey, A1905 \\
\hline SB-31, SB-33 & S. viridis & S.-B. Kim \\
\hline
\end{tabular}

"Abbreviations: SIIA, Sichuan Industrial Institute of Antibiotics, Chengdu, Sichuan, People's Republic of China; KCTC, Korean Collection for Type Cultures, Taejeon, Republic of Korea; DSM, Deutsche Sammlung von Mikroorganismen, Braunschweig, Germany; NCIB, National Collection of Industrial and Marine Bacteria, Ltd., Aberdeen, United Kingdom.

mineral oil layer was removed with a pipette tip. The PCR products were analyzed by electrophoresis of a $5-\mu l$ aliquot through a $1.0 \%$ (wt/vol) agarose gel, stained with ethidium bromide, and visualized by UV transillumination.

Purification of $16 S$ rDNA PCR products. Purification with a GENECLEAN II kit (Bio 101, La Jolla, Calif.) and a Sephaglas BandPrep kit (Pharmacia Biotech., Uppsala, Sweden) was carried out by following the manufacturers' instructions. The PCR products were precipitated with $9 \mu \mathrm{l}$ of $3 \mathrm{M}$ sodium acetate ( $\mathrm{pH} 5.2$ ) and $60 \mu \mathrm{l}$ of isopropanol and resuspended in $50 \mu \mathrm{l}$ of distilled water. Extraction of the PCR products with chloroform was carried out as described previously (16).

Enzymatic digestion of amplified DNA and electrophoresis. Purified DNA (400 ng) and $5 \mu \mathrm{l}$ of chloroform-extracted and unpurified DNA were digested for $2 \mathrm{~h}$ in $10-\mu \mathrm{l}$ volumes with restriction endonucleases according to the manufacturer's instructions. The following two restriction enzymes were used: SmaI and MluI (New England Biolabs, Inc., Beverly, Mass.). Double digestion with SmaI and $M l u \mathrm{I}$ was performed as follows. DNA was first digested for $1 \mathrm{~h}$ at $25^{\circ} \mathrm{C}$ with $S$ maI. Following addition of the buffer recommended by the manufacturer, $M l u I$ was added and the reaction mixture was incubated for $1 \mathrm{~h}$ at $37^{\circ} \mathrm{C}$. The resulting DNA fragments were electrophoresed in $1.5 \%$ (wt/vol) agarose gels in Trisacetate buffer (0.04 M Tris-acetate, $0.001 \mathrm{M}$ EDTA; pH 8.3) at $100 \mathrm{~V}$ for $30 \mathrm{~min}$. The gels were stained with ethidium bromide, and DNA fragments were visualized by UV transillumination and photographed.

A

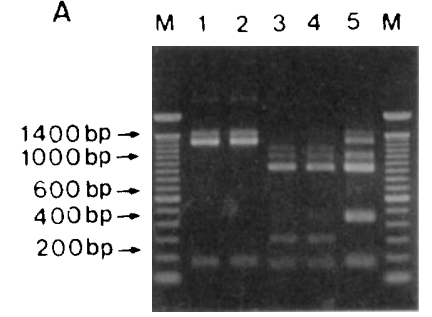

B

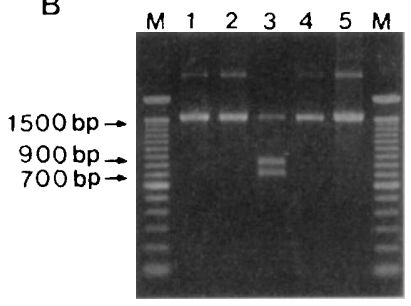

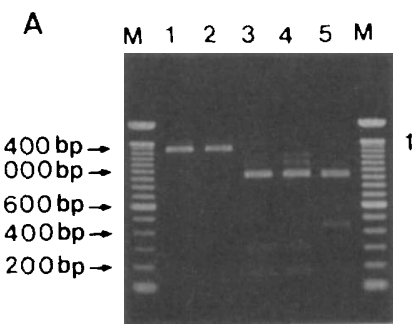

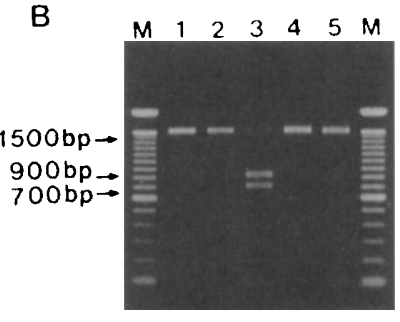

FIG. 2. Restriction patterns of $16 \mathrm{~S}$ rDNAs purified with a Sephaglas BandPrep kit. (A) 16S rDNAs digested with SmaI. (B) 16S rDNAs digested with MluI. Lanes M, 100-bp DNA ladder (Bethesda Research Laboratories); lane 1, S. azurea $\mathrm{K} 161^{\mathrm{T}}$; lane 2, "S. caesia" K163; lane 3, S. cyanea $\mathrm{K} 168^{\mathrm{T}}$; lane 4, S. glauca $\mathrm{K} 169^{\mathrm{T}}$; lane $5, S$. viridis $\mathrm{K} 73^{\mathrm{T}}$.

\section{RESULTS AND DISCUSSION}

Saccharomonospora species have been phylogenetically analyzed by using $16 \mathrm{~S}$ rRNA gene sequences (9). However, many strains cannot be rapidly characterized by $16 \mathrm{~S}$ rRNA sequence analysis. This problem required the development of simple methods for identification of Saccharomonospora species.

Our previous studies showed that each Saccharomonospora species could be differentiated by using genomic DNA restriction fragments and rRNA gene probes. The resulting ribotype patterns are species specific (21). This method is appropriate and more rapid than 16S rRNA sequencing for identification of Saccharomonospora species but is slightly laborious. In the present study PCR-based RFLP analysis of $16 \mathrm{~S}$ rDNAs was performed without probing rRNA genes.

Approximately 1,500-bp $16 \mathrm{~S}$ rDNAs of test strains were amplified by using the universal primers described previously (18) (data not shown). Representative strains of the four validly described Saccharomonospora species (S. azurea K161 ${ }^{\mathrm{T}}$, S. cyanea $\mathrm{K} 168^{\mathrm{T}}$, S. glauca $\mathrm{K} 169^{\mathrm{T}}$, and $S$. viridis $\mathrm{K} 73^{\mathrm{T}}$ ) and " $S$. caesia" K163 were first used in an RFLP analysis of $16 \mathrm{~S}$ rDNAs. The RFLPs of $16 \mathrm{~S}$ rDNAs were determined by using two restriction enzymes, SmaI and MluI. The characteristic restriction profiles generated by digestion with $S m a \mathbf{I}, M l u \mathbf{I}$, and $S m a \mathrm{I}$ plus $M l u I$ allowed representative strains of the four validly described Saccharomonospora species to be differentiated (Fig. 1 to 6$)$.

$S$. azurea $\mathrm{K} 161^{\mathrm{T}}$ and "S. caesia" strains produced the same SmaI, MluI, and SmaI plus MluI restriction patterns (Fig. 1 to 7). "S. caesia" K76" (data not shown) gave RFLP patterns identical to those of other "S. caesia" strains (Fig. 1 to 7). Since it has been reported that $S$. azurea $\mathrm{K} 161^{\mathrm{T}}$ and strains of " $S$. caesia" have identical 16S rRNA sequences (9) and that the two species are closely related $(8,21)$, it was anticipated that

A
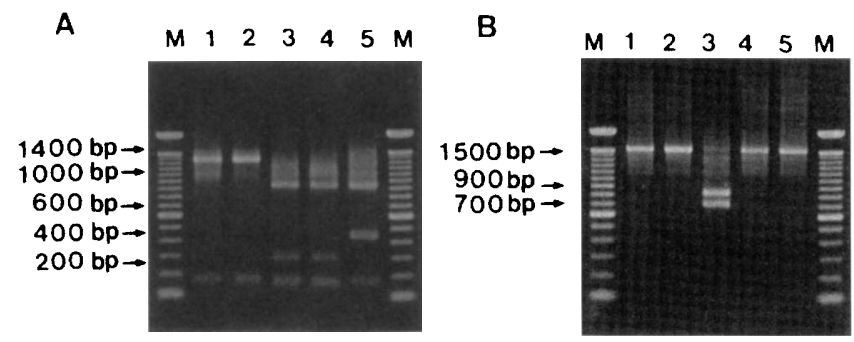

FIG. 1. Restriction patterns of $16 \mathrm{~S}$ rDNAs purified with a GENECLEAN II kit. (A) $16 \mathrm{~S}$ rDNAs digested with SmaI. (B) 16S rDNAs digested with MluI. Lanes M, 100-bp DNA ladder (Bethesda Research Laboratories); lane 1, S. azurea $\mathrm{K} 161^{\mathrm{T}}$; lane 2 , "S. caesia" K163; lane 3 , S. cyanea $\mathrm{K} 168^{\mathrm{T}}$; lane 4 , S. glauca $\mathrm{K} 169^{\mathrm{T}}$; lane $5, S$. viridis $\mathrm{K} 73^{\mathrm{T}}$.

FIG. 3. Restriction patterns of 16S rDNAs precipitated with isopropanol. (A) 16S rDNAs digested with SmaI. (B) 16S rDNAs digested with MluI. Lanes M, 100-bp DNA ladder (Bethesda Research Laboratories); Iane 1, S. azurea $\mathrm{K} 161^{\mathrm{T}}$; lane 2, "S. caesia" K163; lane 3, S. cyanea $\mathrm{K} 168^{\mathrm{T}}$; lane 4, S. glauca $\mathrm{K} 169^{\mathrm{T}}$; lane 5, S. viridis $\mathrm{K} 73^{\mathrm{T}}$. 
A
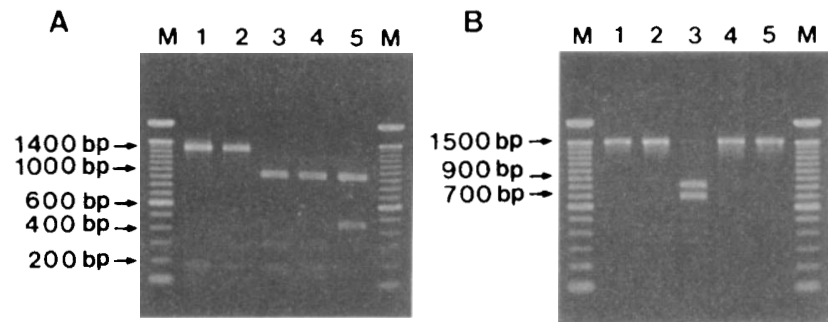

FIG. 4. Restriction patterns of $16 \mathrm{~S}$ rDNAs extracted with chloroform. (A) $16 \mathrm{~S}$ rDNAs digested with SmaI. (B) $16 \mathrm{~S}$ rDNAs digested with MluI. Lanes M 100-bp DNA ladder (Bethesda Research Laboratories); lane 1, S. azurea K161 ${ }^{\mathrm{T}}$; lane 2, "S. caesia" K163; lane 3, S. cyanea $\mathrm{K} 168^{\mathrm{T}}$; lane 4, S. glauca $\mathrm{K} 169^{\mathrm{T}}$; lane 5, S. viridis $\mathrm{K} 73^{\mathrm{T}}$.

these organisms would have the same $16 \mathrm{~S}$ rDNA RFLP patterns. However, DNA-DNA relateness experiments or other taxonomic studies are needed to determine the exact taxonomic relationship between the two species. $S$. cyanea $\mathrm{K} 168^{\mathrm{T}}$ and $S$. glauca $\mathrm{K} 169^{\mathrm{T}}$ gave the same 16S rDNA RFLP patterns after SmaI digestion (Fig. 1A, 2A, 3A, 4A, and 5A). However, digestion of the $16 \mathrm{~S}$ rDNAs with $M l u \mathrm{I}$ allowed the two species to be distinguished (Fig. 1B, 2B, 3B, 4B, and 5B). A MluI restriction site was found only in the $16 \mathrm{~S}$ rDNA of $S$. cyanea $\mathrm{K} 168^{\mathrm{T}}$ (Fig. 1B, 2B, 3B, 4B, and 5B). S. viridis $\mathrm{K} 73^{\mathrm{T}}$ was distinguished from other Saccharomonospora species only by its $S m a$ I restriction profile (Fig. 1A, 2A, 3A, 4A, and 5A).

The additional 10 test strains of $S$. glauca and $S$. viridis gave RFLP patterns identical to those of the corresponding representative strains after $S m a \mathrm{I}$ and MluI digestion (Fig. 7). These observations were in good agreement with the results of a $16 \mathrm{~S}$ rRNA sequence analysis (9) and ribotyping (21); that is, intraspecific differences were not observed in the $S$. glauca, $S$. viridis, and " $S$. caesia" strains when the two analyses were performed (the only exception was $S$. glauca $\mathrm{K} 169^{\mathrm{T}}$, which differed at one nucleotide position from other $S$. glauca strains). Since other strains of $S$. cyanea were not available, RFLP patterns of additional $S$. cyanea strains were not investigated. Five test strains identified as $S$. glauca by their SmaI restriction patterns did not produce a restriction pattern when they were treated with $M l u$ I (Fig. 7B). Thus, we concluded that strains of $S$. cyanea were not present in the additional test strains.

In this study, it was found that purification of PCR products was not necessary for a satisfactory RFLP analysis. Digestion of $16 \mathrm{~S}$ rDNA PCR products purified with commercial purification kits, such as GENECLEAN II and Sephaglas BandPrep kits, was no better than digestion of unpurified PCR products (Fig. 1 and 2). The restriction patterns of the $16 \mathrm{~S}$ rDNAs

A

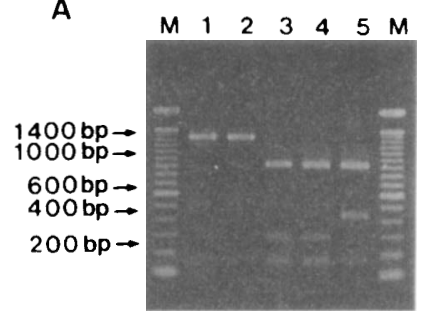

B

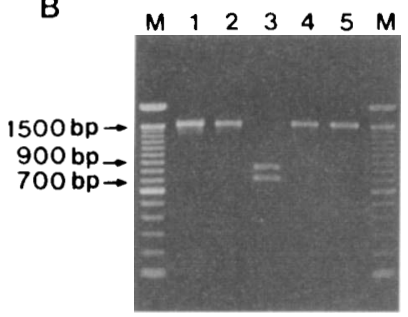

FIG. 5. Restriction patterns of $16 \mathrm{~S}$ rDNAs without any treatment. (A) $16 \mathrm{~S}$ rDNAs digested with SmaI. (B) 16S rDNAs digested with MluI. Lanes M, 100-bp DNA ladder (Bethesda Research Laboratories); lane 1, S. azurea K161 ${ }^{T}$; lane 2 , "S. caesia" K163; lane 3, S. cyanea K168" ; lane 4, S. glauca K169"; lane 5, S. viridis $\mathrm{K} 73^{\mathrm{T}}$.

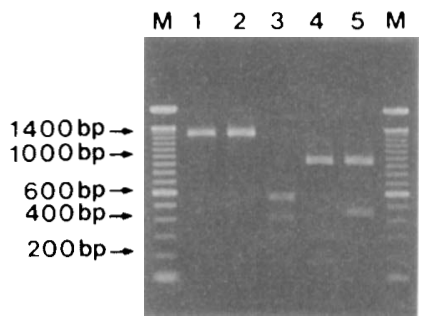

FIG. 6. Restriction patterns of $16 \mathrm{~S}$ rDNAs without any treatment after double digestion with SmaI plus MluI. Lanes M, 100-bp DNA ladder (Bethesda Research Laboratories); lane 1, S. azurea K161"; lane 2, "S. caesia" K163; lane 3, S. cyanea $\mathrm{K} 168^{\mathrm{T}}$; lane 4 , S. glauca $\mathrm{K} 169^{\mathrm{T}}$; lane 5 , S. viridis $\mathrm{K}^{7} 3^{\mathrm{T}}$.

precipitated with isopropanol allowed each species to be differentiated, albeit with difficulty since the patterns were not distinct (Fig. 3). The $16 \mathrm{~S}$ rDNA products extracted with chloroform and directly used without any treatment following the PCR gave good restriction results (Fig. 4 and 5). Therefore, the restriction of DNA was not adversely affected by the small amount of mineral oil still present. The elimination of the purification step is important in terms of saving experimental time and effort in RFLP analyses of unknown strains.

Rapid identification of Saccharomonospora species is now possible by PCR amplification of $16 \mathrm{~S}$ rDNA followed by digestion(s) with $S m a \mathrm{I}$ and $M l u \mathrm{I}$. This represents an alternative to methods based on phenotypic characterization and existing molecular approaches. PCR-RFLP analysis of $16 \mathrm{~S}$ rDNAs is simple, reproducible, and species specific. The method was found to be more rapid and less laborious than ribotyping, as it eliminates the requirement for blotting and probe hybridization procedures.

It has been reported recently that $16 \mathrm{~S}$ rDNAs can be directly amplified by using crude cell lysates from small quantities of bacterial cells $(2,6)$. In our study, $16 \mathrm{~S}$ rDNAs of Saccharomonospora species were also successfully amplified without preliminary DNA extraction and purification from cells by the

A

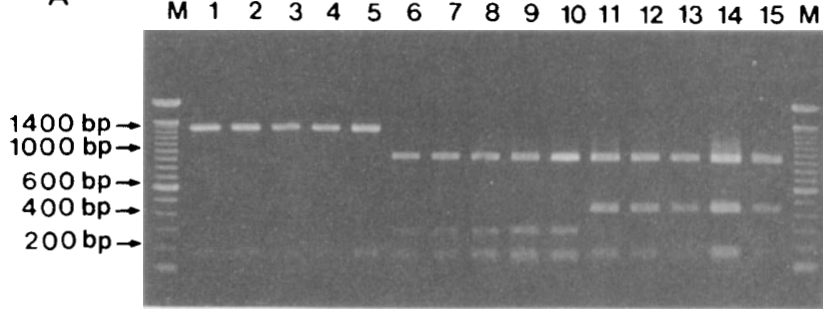

B

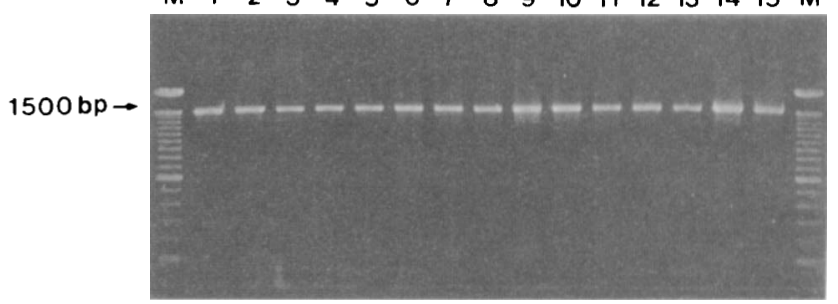

FIG. 7. Restriction patterns of $16 \mathrm{~S}$ rDNAs from 15 test strains. (A) $16 \mathrm{~S}$ rDNAs digested with SmaI. (B) 16S rDNAs digested with MluI. Lanes M, 100-bp DNA ladder (Bethesda Research Laboratories); lane 1, K182; lane 2, K200; lane 3, SB-01; lane 4, SB-22; lane 5, SB-58; lane 6, K179; lane 7, K194; lane 8, K195; lane 9, K202; lane 10, SB-37; lane 11, K185; lane 12, K191; lane 13, K197; lane 14, SB-31; lane 15, SB-33. 
method described previously (data not shown) (6). Our results demonstrate that a more rapid method for bacterial characterization based on 16S rDNA RFLP analysis may be possible.

\section{ACKNOWLEDGMENTS}

This work was supported by grants HS331S and NU00970 from the Ministry of Science and Technology of the Republic of Korea.

We are grateful to Yong Kook Shin for helpful discussions.

\section{REFERENCES}

1. Barrowcliff, D. E., and P. G. Arblaster. 1968. Farmer's lung: a study of an early acute fatal case. Thorax 23:490-500.

2. Frothingham, R., R. L. Allen, and K. H. Wilson. 1991. Rapid 16S ribosomal DNA sequencing from a single colony without DNA extraction or purification. BioTechniques 11:42-44.

3. Greene, J. G., M. W. Treuhaft, and R. M. Arnsell. 1981. Hypersensitivity pneumonitis due to Saccharomonospora viridis diagnosed by inhalation challenge. Ann. Allergy 47:449-452.

4. Greiner-Mai, E., F. Korn-Wendisch, and H. J. Kutzner. 1988. Taxonomic revision of the genus Saccharomonospora and description of Saccharomonospora glauca sp. nov. Int. J. Syst. Bacteriol. 38:398-405.

5. Greiner-Mai, E., R. M. Kroppenstedt, F. Korn-Wendisch, and H. J. Kutzner 1987. Morphological and biochemical characterization and emended descriptions of thermophilic actinomycetes species. Syst. Appl. Microbiol. 9:97-109.

6. Hiraishi, A., Y. K. Shin, Y. Ueda, and J. Sugiyama. 1994. Automated sequencing of PCR-amplified 16S rDNA on 'Hydrolink' gels. J. Microbiol. Methods 19:145-154.

7. Kalakoutskii, L. V. 1964. A new species of the genus MicropolysporaMicropolyspora caesia n. sp. Mikrobiologiya 33:765-768.

8. Kim, S.-B. 1995. Polyphasic taxonomic studies on the genus Saccharomonospora and related taxa. Ph.D. thesis. University of Newcastle upon Tyne, Newcastle upon Tyne, United Kingdom.
9. Kim, S.-B., J.-H. Yoon, H. Kim, S. T. Lee, Y.-H. Park, and M. Goodfellow. 1995. A phylogenetic analysis of the genus Saccharomonospora conducted with 16S rRNA gene sequences. Int. J. Syst. Bacteriol. 45:351-356.

10. Kurup, V. P. 1981 . Taxonomic study of some members of Micropolyspora and Saccharomonospora. Microbiologica (Bologna) 4:249-259.

11. Kurup, V.P. 1984. Thermophilic actinomycetes, their role in hypersensitivity pneumonitis, p. 145-159. In L. Ortiz-Ortiz, L. F. Bojalil, and V. Yakoleff (ed.), Biological, biochemical and biomedical aspects of actinomycetes. Academic Press, Orlando, Fla.

12. Lechevalier, M. P., and H. A. Lechevalier. 1970. A critical evaluation of the genera of aerobic actinomycetes, p. 393-405. In H. Prauser (ed.). The Actinomycetales. Gustav Fischer Verlag, Jena, Germany.

13. Nonomura, H., and Y. Ohara. 1971. Distribution of actinomycetes in soil. X. New genus and species of monosporic actinomycetes. J. Ferment. Technol. 49:895-903.

14. Runmao, H. 1987. Saccharomonospora azurea sp. nov., a new species from soil. Int. J. Syst. Bacteriol. 37:60-61.

15. Runmao, H., C. Lin, and W. Guizhen. 1988. Saccharomonospora cyanea sp. nov. Int. J. Syst. Bacteriol. 38:444-446.

16. Sambrook, J., E. F. Fritsch, and T. Maniatis. 1989. Molecular cloning: a laboratory manual, 2nd ed., p. 14.19. Cold Spring Harbor Laboratory, Cold Spring Harbor, N. Y.

17. Skerman, V. B. D., V. McGowan, and P. H. A. Sneath (ed.). 1980. Approved lists of bacterial names. Int. J. Syst. Bacteriol. 30:225-420.

18. Stackebrandt, E., and W. Liesack. 1993. Nucleic acids and classification, p. 152-189. In M. Goodfellow and A. G. O'Donnell (ed.), Handbook of new bacterial systematics. Academic Press, London, United Kingdom.

19. Weisburg, W. G., S. M. Barns, D. A. Pelletier, and D. J. Lane. 1991. 16S ribosomal DNA amplification for phylogenetic study. J. Bacteriol. 173:697703.

20. Woese, C. R. 1987. Bacterial evolution. Microbiol. Rev. 51:221-271.

21. Yoon, J.-H., H. Kim, S.-B. Kim, H.-J. Kim, W. Y. Kim, S. T. Lee, M. Goodfellow, and Y.-H. Park. 1996. Identification of Saccharomonospora strains with genomic DNA fragments and rRNA gene probes. Int. J. Syst. Bacteriol. 46:502-505. 